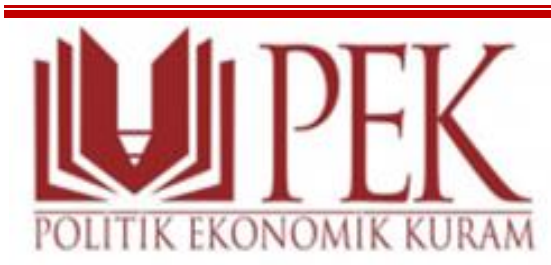

2020, Cilt 4, Sayı 2, 255-268

\section{POLİTIKK EKONOMIK KURAM}

E-ISSN: 2587-2567

https://dergipark.org.tr/tr/pub/pek

Doi: $10.30586 /$ pek.804706

Makale Geliş Tarihi: 03.10.2020

Makale Kabul Tarihi: 26.10.2020

Araştırma Makalesi

Çevresel Bozulmalarda Terörizm ve Kamu Harcamalarının Etkisi

Günay ÖZCAN ${ }^{1}$, Çiğgem KARTER ${ }^{2}$

The Impact of Terrorism and Government Expenditures in Environmental Disorders

\begin{abstract}
In the theory of economics, if the quantity of a good or service supplied in the market is more than Controlling environmental degradation, which has an important place in the international literature, has been one of the main problems for economies. For this reason, the aim of this study is to examine the environmental relationship of public expenditures and terrorism, whose effects on environmental degradation are being discussed, between 20022017 in countries where terrorism is intense. Cross-section dependence and homogeneity and unit root tests were used in the study. Then the causality relationship was examined. Cross-section dependence, heterogeneity and unit root tests, which are among the panel data analysis methods, were applied in the study. The results show that terrorism and public spending are the cause of environmental degradation throughout the panel. When analyzed by country, causality relationship was determined among the variables.
\end{abstract}

Keywords: Terrorism, Government Expenditure, Environmental Degradation, Panel Causality

JEL Codes: C33, O13, H50

$\ddot{O} z$

Uluslararası gündemde önemli bir yer tutan çevresel bozulmaların kontrol altına alınması ekonomiler için başlıca problemlerden biri olmuştur. Bu sebeple çalışmanın amacı çevre bozulmalarında etkileri tartışılmakta olan kamu harcamaları ve terörizmin etkisini terörün yoğun olduğu ülkelerde 2002-2017 dönemleri arasında incelemektir. Çalışmada panel ver analizi metotlarından olan yatay kesit bağımlılığı, homojenlik ve birim kök testleri uygulanmıştır. Daha sonra nedensellik ilişkisine bakılmıştır. Elde edilen sonuçlar panel genelinde terörizm ve kamu harcamalarının çevresel bozulmaların nedeni olduğunu göstermektedir. Ülke bazında ise yine değişkenler arasında nedensellik ilişkisinin varlı̆̆ tespit edilmiştir.

Anahtar Kelimeler: Terörizm, Kamu Harcamaları, Çevresel Bozulmalar, Panel Nedensellik

\footnotetext{
${ }^{1}$ Dr. Öğr. Üyesi, Necmettin Erbakan Üniversitesi, Siyasal Bilgiler Fakültesi, gakel@erbakan.edu.tr, Orcid:00000002-1950-4255

2Dr, Bağımsız Araştırmacı, cigdemkarter22@hotmail.com, Orcid: 0000-0002-1285-5394
} 


\section{Giriş}

20. yüzyılda gerçekleşen sanayileşme ve teknolojik gelişmelerin etkisi ile üretim ve tüketim faaliyetlerinin hızla artması fosil yakıtlarının yoğun bir şekilde kullanılmasına neden olarak çevreye ciddi zararlar vermiştir. Bunun sonucunda hava, su ve toprak hizla kirlenmeye ve çevrenin doğal dengesi bozulmaya başlamıştır. Küresel ısınma ve iklim değişiklikleri, ozon tabakasının incelmesi, biyolojik çeşitlilikteki azalma gibi daha birçok çevresel bozulma sadece bir ülkeyi değil, yerine göre birkaç ülkeyi hatta küresel olarak tüm dünyayı etkiler duruma gelmiştir (Biyan, 2014).

Çevre ve çevre sorunları, sahip oldukları özellikler nedeniyle kamusal mal ve hizmet olarak nitelendirilmekte ve kamu harcamalarının çevre kirliliği üzerindeki etkisi; ölçek etkisi, teknoloji etkisi ve kompozisyon etkisi şeklinde ifade edilebilmektedir. Kamu harcamalarının; kamu malları lehine yeniden yapılandırılması ekonomik büyümeyi artırarak çevresel baskıyı artırmakta ve ölçek etkisine neden olmaktadır. Teknoloji etkisi ise AR-GE fonlarındaki artış ve teknolojik difüzyon ile daha temiz çevre için teknolojinin geliştirilmesini ve kullanılmasına olanak tanımaktadır. Kompozisyon etkisi de çevreyi olumlu yönde etkilemektedir. Kamu harcamalarının, çevreyi en çok kirleten fiziksel sermaye yoğun endüstrilerden insan sermayesi yoğun faaliyetlere yönelmesi çevresel kalitenin iyileştirilmesine katkıda bulunmaktadır (Lopez vd., 2011: 4-5).

Ülkeler, çevresel sorunların çözümüne yönelik çeşitli yöntemler ve kontrol mekanizmaları geliştirmiştir. Çevrenin kamusal mal niteliğinde olması; çevresel bozulmayı önlemek ve dışsallıkların içselleştirilmesi için kamusal önlemler alınması bu anlamda önem taşımaktadır (Mutlu, 2006: 62). Çevresel politika araçlarından olan ve kamu otoritesi tarafından uygulanan ve bir anlamda teşvik edici, caydırıcı ve sınırlayıcı nitelikleri bünyesinde barındıran kamu araçları arasında; çevre vergi ve harçları, kirlilik sertifikaları, çevresel sübvansiyonlar, çevresel etki değerlemesi, performans bonoları ve depozit geri ödemeleri vb. uygulamalar bulunmaktadır (Kaypak, 2013: 26). Çevre politikaları farklı isimlerle ifade edilse de uygulanan bu politikalar, çevresel bozulmayı iyileştirerek çevre kalitesini artırmayı ve ekonomik kayıpları en aza indirgemeyi hedeflemektedir.

Çevresel bozulmaların bir diğer sebeplerinden biri de terörizmdir. Terörün yol açtığı çevresel zararlar, karasal çatışmaları, terörist kampları ve üsleri, eğitim faaliyetlerini, enerji tüketimi ile ilişkili olan karbondioksit emisyonlarını $\left(\mathrm{CO}_{2}\right)$ içerir, fakat tahribatlar sadece bunlarla sınırlı değildir (Bildirici ve Gökmenoğlu, 2020). Aynı zamanda kimyasal terör saldırıları da hem insan sağlığına hem de çevreye oldukça büyük zararlar vermektedir. Verilen zararın etkisi kullanılan kimyasal maddenin türüne ve miktarına bağlı olarak değişmektedir (Hrdina vd., 2010). Kitle imha silahlarında kullanılan demir, bakır, çelik ve uranyum gibi ağır metaller de terörün çevreye verdiği zararlar arasındadır.

Terörün çevre tahribatları çok boyutlu olduğundan dolaylı ve doğrudan olarak bu etkiler incelene bilinir. Yerleşim yerlerine, kırsal alanlara ve iletişim ağlarına bomba ve patlama gibi yapılan terör saldırıları olarak görülen doğrudan etkiler daha kısa dönemli zararlara sebep olurken dolaylı etkiler daha uzun dönemde ve yıkıcı tahribatlara sebep olabilmektedir (Mannion, 2003). Kitle imha silahlarında kullanılan metaller, silah üretimi için kurulan sanayilerin enerji tüketimine bağlı olarak salınan karbon emisyonu, petrokimya tesisleri ile tehlikeli maddelerin havaya, suya ve toprağa sızdırılması, tarım arazilerinin tahrip olması, terörün her boyutuyla çevre bozulmalarında ne kadar etkili olduğunu göstermektedir.

Belirtilen tüm bu etkiler 1şı̆̆ında bu çalışmada, terörün ve kamu harcamalarının çevre bozulmalarındaki etkisini terörün en yoğun olduğu ilk 10 ülke içerisinde yer alan Irak, Nijerya, Pakistan, Hindistan, Yemen, Filipinler ve Kongo üzerinde etkisini 2002-2017 dönemleri arasında incelemek amaçlanmaktadır. Belirtilen ülkelerde hem terörle mücadele ile hem de 
diğer kamu politikaları yoluyla yapılan kamu harcamalarının doğrudan ya da dolaylı olarak çevre bozulmalarına etkisi de incelenmiştir.

Çalışmanın ikinci kısımda, terörizmin ve kamu harcamalarının çevresel bozulmalar üzerindeki etkisine yönelik literatür taraması yapılmıştır. Üçüncü kısımda veri setinden bahsedilmekte ve çalışmanın dördüncü bölümünde ise panel veri analizine yönelik metodoloji ve analiz bulguları yer almaktadır. Son olarak, konuya özgü bulguların tartışılacağı sonuç ve değerlendirme k1smina yer verilmektedir.

\section{Literatür Taraması}

$\mathrm{Bu}$ çalışmanın temel amacı, çevresel bozulmalar üzerinde kamu harcamaları ve terörizmin etkilerini incelemektir. Literatür araştırmasında öncelikle çevresel bozulmalar ile kamu harcamaları arasındaki ilişski incelenmiş daha sonra çevre ile terörizm arasındaki ilişkiye yer verilmiştir.

Son ampirik çalışmalar, kamu harcamaları seviyesindeki ve bileşimindeki değişikliklerin çevre kirliliği seviyelerini önemli ölçüde etkilediğini göstermiştir (Bernauer ve Koubi, 2006; Halkos ve Paizanos, 2013; López vd., 2011; López ve Palacios, 2014). Literatürde farklı bölge ve ülkeler için bu ilişkinin varlığını araştıran birçok çalışma mevcuttur.

Lopez ve Galinato (2007) kamu harcamalarını piyasa verimliliği üzerindeki etkisine göre iki sınıflandırmaya ayırmıştır. Birincisi; piyasa başarısızlığını azaltan, kamu malları üzerine yapılan kamu harcamaları (Ar-Ge, eğitim ve sağlık hizmetleri ve bazı altyapı ve çevre koruma yatırımları), ikincisi ise; özel mallara yapılan ve piyasa başarısızlığını azaltmayan, hatta piyasadaki verimsizliği artırabilecek kamu harcamalarını ifade etmektedir. Tarımsal sübvansiyonlar ve fosil yakıt üretimi teşvikleri bu tür harcamalara örnektir. Ampirik analizlerinde; bu bahsedilen sınıflandırmayı, 15 Latin Amerika ülkesi için 1985-2001 dönemi verileri ile panel regresyon (FE-RE) ve GMM yöntemlerini kullanarak araştırmışlardır. Elde edilen bulgularda; yapılan kamu harcamalarında kamu mallarının payının artırılması, özel mallara yapılan sübvansiyon paylarının ise azaltılması gerektiğini ve bu doğrultuda çevresel bozulmaların azalacağı sonucuna ulaşmışlardır. Aynı şekilde Lopez vd. (2011) kamu harcamalarının çevre kirliliği üzerindeki etkisini, hava kirliliği için; 1986-1999 dönemi verileri, su kirliliği için 1980-2005 dönemi verileri yardımıyla OLS VE GMM yöntemlerini kullanarak analiz etmişlerdir. Ampirik bulguda; toplam kamu harcamalarının çevre kirliliği üzerinde belirsiz bir etkisi olmasına rağmen, kamu harcamalarının toplam harcamalardaki yüzdesinin önemini vurgulanmakta ve kamu mallarının payındaki artışın emisyon düzeylerini azalttığı öngörülmektedir.

Üretim kaynaklı çevre kirliliğine ilişkin olarak, Bernauer ve Koubi (2006), kamu harcamalarının hava kirliliği üzerindeki etkisini 42 ülke için 1971-1996 dönemine ilişkin veriler yardımıyla OLS yöntemi uygulayarak incelemişlerdir. Ulaşılan sonuçlara göre kamu harcamalarının GSYH içindeki payının \%1 oranında artması havadaki $\mathrm{SO}_{2}$ (Sülfürdioksit) oranını \%2.33 oranında artırmaktadır. Fakat küçük boyutta da olsa kamu harcamalarındaki artışın devamlı olması hava kalitesindeki olumsuzluğu azaltmıştır.

Halkos ve Paizanos (2016) kamu harcamalarının $\mathrm{CO}_{2}$ emisyonu üzerindeki etkisini $\mathrm{ABD}$ için 1973-2013 dönemine ait verilerle VAR analizi uygulayarak araştırmışlardır. Elde edilen bulguya göre; kamu harcamaları üretim ve tüketimden kaynaklanan emisyonları azaltmakta, uygulanan vergi indirimi ise tüketime dayalı karbon emisyonunu artırmaktadır.

İncelenen birçok çalışma tipik olarak üretim kaynaklı çevre kirliliğine odaklanmıştır, ancak bazı çalışmalar tüketim kaynaklı çevre kirliliğinin önemini vurgulamaktadır. Islam ve Lopez (2015) kamu harcamalarının hava kirliliği üzerindeki etkisini ABD için farklı kirleticilere ilişkin 1983-2008 $\left(\mathrm{O}_{3}\right)$, 1985-2008 $\left(\mathrm{SO}_{2}\right)$, 2000-2008 (PM 2,5) dönemi verilerini kullanarak 
GMM yöntemi ile analiz etmişlerdir. Ampirik bulgular; devlet ve yerel yönetimler tarafindan özel mallardan sosyal ve kamu mallarına yapılan harcamalardaki artışın hava kirliliği konsantrasyonlarını azalttığını, federal harcamaların bileşimindeki değişikliklerin hava kirliliği üzerinde hiçbir etkisinin olmadığını göstermektedir.

Kişi başına düsşen gelirin yüksek olduğu ülkelerde $\mathrm{SO}_{2}, \mathrm{CO}_{2}$ ve partiküller madde gibi hava kirleticilerinin kişi başına düşen emisyonlarının düşük olduğu yadsınamaz bir gerçektir. Aynı şekilde düşük gelirli ekonomilerde çevresel bozulmanın arttığına ilişkin çalı̧̧malar çevresel göstergeler ile kişi başına düşen gelir arasında sistematik bir ilişkinin varlığına işaret etmektedir (Cole, 2004: 439). Zhang vd. (2017), kamu harcamalarının çevre kirliliği üzerindeki etkisini Çin için, 2002-2014 dönemine ilişkin veriler yardımıyla GMM yöntemi ile analiz etmişlerdir. Ulaşılan sonuçlar; kamu harcamalarının $\mathrm{SO}_{2}$ ve $\mathrm{COD}$ (kimyasal oksijen talebi) üzerindeki toplam etkisi negatif yöndedir. Kamu harcamalarının dolaylı etkisi ise, kişi başına düşen GSYH'nin çevresel kalite üzerindeki etkisine bağlıdır. Kişi başına düşen GSYH arttıkça, $\mathrm{SO}_{2}$ ve kurum emisyonları aşağı yönlü eğilimler gösterirken COD artmaya devam etmektedir.

Kamu harcamalarının çevresel bozulmalar üzerindeki etkisi; kamu harcamalarının seviyesindeki ve bileşimindeki değişikliklere, spesifik kirleticiye ve araştırılan ülke veya bölgeye bağlı olabilmektedir. Bu doğrultuda Tablo 1'de farklı çalışma alanları, dönemleri, çeşitli metodolojik yaklaşımları ve çeşitli bulguları kapsayan seçilmiş örnekler sunulmaktadır. 
Tablo 1: Çevresel Bozulma ve Kamu Harcamaları Arasındaki İlişkiyi İnceleyen Literatür

\begin{tabular}{|c|c|c|c|}
\hline Yazar(lar) & Yöntem & Dönem-Ülke(ler) & 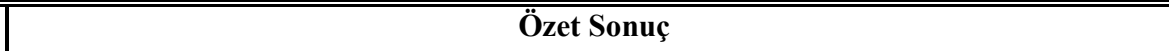 \\
\hline Carlsson ve Lundström (2001) & GMM & $\begin{array}{l}1975-1995 \\
75 \text { Ülke }\end{array}$ & $\begin{array}{l}\text { Çalışmada ülkedeki ekonomik özgürlüğün artmasının, kamu harcamaları ile } \\
\mathrm{CO}_{2} \text { emisyonunu artışının doğru orantılı olduğu sonucuna ulaşmışlardır. }\end{array}$ \\
\hline Bernaver ve Koubi (2006) & OLS & $\begin{array}{l}\text { 1971-1996 } \\
42 \text { Ülke }\end{array}$ & $\begin{array}{l}\text { Ampirik sonuca göre; kamu harcamalarının GSYH içindeki payının \%1 oranında artmas } 1 \\
\text { havadaki } \mathrm{SO}_{2} \text { (kükürtdioksit) oranını } \% 2.33 \text { oranında artırmaktadır. Fakat küçük boyutta da } \\
\text { olsa kamu harcamalarındaki artışı devamlı olması hava kalitesindeki olumsuzluğu } \\
\text { azaltmışır. }\end{array}$ \\
\hline Lopez vd. (2011) & OLS, GMM & $\begin{array}{l}\text { 1986-1999 } \\
38 \text { Ülke (Hava kirliliği için) } \\
47 \text { Ülke (Su Kirliliği için) }\end{array}$ & $\begin{array}{l}\text { Kamu harcamalarının kamu mallarına yönelik yapılması kirliliği azaltmaktadır. Toplam } \\
\text { kamu harcamalarının ise kirlilik üzerinde belirsiz bir etkisinin olduğu öngörülmüştür. }\end{array}$ \\
\hline Halkos ve Paizanos (2013) & GMM & $\begin{array}{l}\text { 1980-2000 } \\
77 \text { Ülke }\end{array}$ & $\begin{array}{l}\text { Analizde; kamu harcamalarının kişi başı } \mathrm{SO}_{2} \text { emisyonu üzerinde doğrudan negatif etkisi } \\
\text { olduğu, } \mathrm{CO}_{2} \text { üzerinde doğrudan bir etkinin olmadığ } 1 \text { görülmüştür. Fakat gelir düzeyi arttıkça } \\
\mathrm{SO}_{2} \text { emisyonu dolaylı olarak pozitif etkiye, } \mathrm{CO}_{2} \text { emisyonu ise dolaylı olarak negatif etkiye } \\
\text { sahip olmaktadır. }\end{array}$ \\
\hline Lopez ve Palacios (2014) & GMM & $\begin{array}{c}\text { 1995-2008 } \\
\text { Gelişmiş } 12 \text { Avrupa Ülkesi }\end{array}$ & $\begin{array}{l}\text { Mali harcamaların } \mathrm{GSYH} \text { içindeki payının artırılması (kamu mallarına yönelik harcamalar } \\
\text { ve sübvansiyonlar); } \mathrm{SO}_{2} \text { ve } \mathrm{O}_{3} \text { konsantrasyonunu önemli ölçüde azaltmakta, } \mathrm{NO}_{2} \text { üzerinde } \\
\text { ise etkisi bulunmamaktadır. }\end{array}$ \\
\hline Islam ve Lopez (2015) & GMM & $\begin{array}{c}1983-2008\left(\mathrm{O}_{3}\right) \\
1985-2008\left(\mathrm{SO}_{2}\right) \\
2000-2008(\mathrm{PM} 2,5) \\
\text { ABD }\end{array}$ & $\begin{array}{l}\text { Sonuçlar, devlet ve yerel yönetimler tarafindan özel mallardan sosyal ve kamu mallarına } \\
\text { yapılan harcamalardaki artışın hava kirliliği konsantrasyonlarını azalttığını, federal } \\
\text { harcamaların bileşimindeki değişikliklerin hava kirliliği üzerinde hiçbir etkisinin olmadığını } \\
\text { göstermektedir. }\end{array}$ \\
\hline
\end{tabular}




\begin{tabular}{|c|c|c|c|}
\hline Galinato ve Galinato (2016) & $\begin{array}{c}\text { OLS } \\
\text { GMM }\end{array}$ & $\begin{array}{l}\text { 1986-1999 } \\
8 \text { Ülke }\end{array}$ & $\begin{array}{l}\text { Kısa dönemde kamu harcamalarının orman alanlarını tarım arazilerine dönüştürme yönünde } \\
\text { artmasının } \mathrm{CO}_{2} \text { emisyonununu artırdığı sonucuna ulaşılmıştır. Uzun dönemde ise kamu } \\
\text { harcamalarının } \mathrm{CO}_{2} \text { emisyonu üzerinde istatistiksel olarak anlamlı bir etkisi yoktur. }\end{array}$ \\
\hline Adewuyi (2016) & Panel & $1990-2015$ & $\begin{array}{l}\text { Analizde uzun vadede kamu harcamalarındaki \% 1'lik bir artışın karbon emisyonlarını \% } \\
1,15 \text { oranında azalttığı gözlemlenmiştir. }\end{array}$ \\
\hline Halkos ve Paizanos (2016) & $\begin{array}{l}\text { Bayesian VAR } \\
\text { Analizi }\end{array}$ & $\begin{array}{c}1973-2013 \\
\text { ABD }\end{array}$ & $\begin{array}{l}\text { Genişletici mali harcamalar tüketim ve üretim kaynaklı } \mathrm{CO}_{2} \text { emisyonunu negatif } \\
\text { etkilemektedir. }\end{array}$ \\
\hline Galinato ve Islam (2017) & GMM & $\begin{array}{l}\text { 1986-1999 } \\
95 \text { Ülke }\end{array}$ & $\begin{array}{l}\text { Ampirik bulgular; demokratik ülkelerde devletin piyasa başarısılılklarını çözmek için kamu } \\
\text { mallarına yaptığı harcamaları artırması sonucunda CO (Karbonmonoksit) ve } \mathrm{NO}_{2} \\
\text { (Azotdioksit) salınımının azaldığı ve otokrat ülkelerde ise bunun tam tersinin geçerli olduğu } \\
\text { yönündedir. }\end{array}$ \\
\hline Zhang vd. (2017) & GMM & $\begin{array}{l}\text { 2002-2014 } \\
\text { Çin }\end{array}$ & $\begin{array}{l}\text { Toplam etki: Kamu harcamaları } \mathrm{SO}_{2} \text { ve } \mathrm{COD} \text { (kimyasal oksijen talebi) üzerinde negatif } \\
\text { etkiye sahip. } \\
\text { Dolaylı etki: Kamu harcamalarının dolaylı etkisi, kişi başına düşen } \mathrm{GSYH} \text { 'nin çevresel } \\
\text { kalite üzerindeki etkisine bağlıdır. Kişi başıa düşn GSYH arttıkça, } \mathrm{SO}_{2} \text { ve kurum } \\
\text { emisyonları aşağı yönlü eğilimler gösterirken COD artmaya devam etmektedir. }\end{array}$ \\
\hline $\begin{array}{l}\text { Katırcioğlu ve Katırcioğlu } \\
\qquad(2018)\end{array}$ & $\begin{array}{l}\text { ARDL } \\
\text { Granger Nedensellik } \\
\text { Testi }\end{array}$ & $\begin{array}{l}\text { 1960-2013 } \\
\text { Türkiye }\end{array}$ & $\begin{array}{l}\text { Ampirik sonuca göre; Genişletici maliye politikası } \mathrm{CO}_{2} \text { emisyonu üzerinde negatif etkiye } \\
\text { sahiptir. Ayrıca kısa ve uzun dönemde mali değişkenlerden } \mathrm{CO}_{2} \text { emisyonuna doğru } \\
\text { nedensellik mevcuttur. }\end{array}$ \\
\hline Yuelan vd. (2019) & ARDL & $\begin{array}{l}\text { 1980-2016 } \\
\text { Çin }\end{array}$ & $\begin{array}{l}\text { Elde edilen bulgu; genişletici maliye politikasının uzun vadede çevresel bozulmayı artırdığı } \\
\text { yönündedir. }\end{array}$ \\
\hline Ike vd. (2020) & $\begin{array}{c}\text { OLS } \\
\text { Todo Yamamato } \\
\text { Nedensellik Analizi }\end{array}$ & $\begin{array}{c}\text { 1972-2014 } \\
\text { Tayland }\end{array}$ & $\begin{array}{l}\text { Maliye politikasının düşük oranda } \mathrm{CO}_{2} \text { emisyonu yayan yakıt kaynakları (doğal gaz) } \\
\text { üzerinde olumlu etkisi olurken, yüksek oranda } \mathrm{CO}_{2} \text { emisyonu yayan yakıt kaynakları (ham } \\
\text { petrol türevleri) üzerinde olumsuz etkisi vardır. Ayrıca maliye politikasından } \mathrm{CO}_{2} \\
\text { emisyonuna doğru tek yönlü bir nedensellik vardır. }\end{array}$ \\
\hline
\end{tabular}


Özcan, G. \& Karter, Ç. (2020), “Çevresel Bozulmalarda Terörizm ve Kamu Harcamalarının Etkisi”, Politik Ekonomik Kuram, 4 (2), 255-268.

Mannion (2003), çalışmasında terörün ve savaşların dünyada çevreye verdikleri tahribatları ve kazanımlarını çok yönlü olarak ele almıştır. Çalışmada çevrenin terörden doğrudan ve dolaylı olarak etkileri detaylı olarak incelenmiş olup konuya yönelik çalışmaların artması gerektiği vurgulanmıştır.

Bildirici ve Gökmenoğlu (2020), terörizmin çevre kirliliği üzerindeki etkisini 9 ülke (Afganistan, Irak, Nijerya, Pakistan, Filipinler, Suriye, Somali, Tayland ve Yemen) için 1975-2017 dönemine ilişkin veriler yardımıyla ANOVA ve nedensellik testleri ile incelemişlerdir. Analiz sonucunda; terörizmin $\mathrm{CO}_{2}$ salınımını artırarak çevre kirliliğine neden olduğu ayrıca son dönemlerde yüksek teknolojili ekipmanların kullanılması nedeniyle terörizme yönelik enerji talebinin her geçen gün artmasının $\mathrm{CO}_{2}$ salınımını daha çok artırdığını ifade etmişlerdir.

Literatür araştırması sonucunda ele aldığımız çalışmalar dikkate alındığında; terörizmin yoğunlukla ekonomik büyüme ve doğrudan yabancı sermaye yatırımları üzerine etkisi incelenmiş olup çevresel bozulmalar ile ilişkisi çok az sayıda ele alınmıştır. Bu anlamda çalışmamızın literatüre katkı yapacağ

\section{Veri Seti}

Bu çalışmada, 7 Ülkenin (Filipinler, Hindistan, Irak, Kongo, Nijerya, Pakistan ve Yemen) kamu harcamaları ve terörizmin çevresel bozulmalar üzerindeki etkisi 2002-2017 dönemi verileri ile analiz edilmiştir. Ele alınan ülkeler; terörizmi en yoğun yaşayan ülkeler olarak seçilmiş ve dönem aralığında ise verilerin ulaşılabilirliği göz önünde bulundurulmuştur.

Tablo 2'de çalışmada kullanılan değişkenler ve açıklamalarına yer verilmiştir. Buna göre, $\mathrm{CO}_{2}$ emisyonu değişkeni modelde bağımlı değişken olarak kullanılmıştır. Bağımsız değişken olarak terörizm, kamu harcamaları, enerji arzı ve gelir değişkenleri kullanılmıştır. Çalışmada kullanılan değişkenlere; Dünya Bankası (WDI), Uluslararası Enerji Ajansı (IEA) ve İktisadi ve Barış Enstitüsü (IEP) veri tabanlarından ulaşılmıştır.

Tablo 2: Çalışmada Kullanılan Değişkenler ve Açıklamaları

\begin{tabular}{|c|c|c|c|}
\hline $\begin{array}{c}\text { Değişken } \\
\text { Simgesi }\end{array}$ & Açıklaması & Kaynağı & Dönemi \\
\hline $\boldsymbol{c o 2}$ & Karbondioksit Emisyonu & Uluslararası Enerji Ajansı (IEA) & $2002-2017$ \\
\hline $\boldsymbol{t e r}$ & Terörizm Endeksi & İktisadi ve Barış Enstitüsü (IEP) & $2002-2017$ \\
\hline $\boldsymbol{g o v h}$ & $\begin{array}{c}\text { Kamu harcamalarının GSYH içindeki } \\
\text { yüzdelik oranı }\end{array}$ & Dünya Bankası (WDI) & $2002-2017$ \\
\hline $\boldsymbol{e n s u p}$ & Enerji Arzı Endeksi & Uluslararası Enerji Ajansı (IEA) & $2002-2017$ \\
\hline $\boldsymbol{g d p}$ & GSYH & Dünya Bankası (WDI) & $2002-2017$ \\
\hline
\end{tabular}

Çalışmada kullanılan ekonometrik model aşağıdaki gibi oluşturulmuştur:

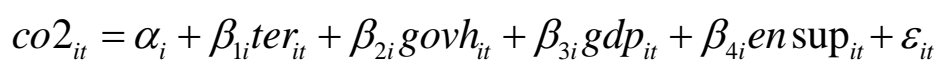

Çalışmanın analiz kısmı metodolojik olarak 3 aşamadan oluşmaktadır. İlk olarak modelde kullanılan değişkenlerde ve modelde yatay kesit bağımlılı̆̆ı araştırılmış ve homojenite testi uygulanmıştır. Yatay kesit bağımlılığı $L M, C D_{L M}, C D$ ve $L M_{a d j}$ testleri uygulanarak tespit edildikten sonra, ikinci aşamada serilerin durağan olup olmadığı Hadri ve Kurozumi Panel-KPSS ikinci nesil birim kök testiyle araştırılmıştır. Sonraki aşamada ise seriler arasındaki nedensellik 
Özcan, G. \& Karter, Ç. (2020), “Çevresel Bozulmalarda Terörizm ve Kamu Harcamalarının Etkisi”, Politik Ekonomik Kuram, 4 (2), 255-268.

ilişkilerinin ortaya konulması amacıyla Emirmahmutoğlu ve Köse (2011) nedensellik testi uygulanmıştır.

\section{Metodoloji Ve Analiz Bulguları}

\subsection{Yatay Kesit Bă̆ımlılı̆̆ı ve Homojenite Testi}

Yatay kesit bağımlılığı yöntemleri ilk kez Breusch ve Pagan (1980) tarafından geliştirilmiş ve hata terimlerinin birbirleriyle ilişkili olması şeklinde ifade edilmektedir. Breusch ve Pagan (1980) kesitler arasındaki bağımlılı̆̆ın tespiti için $L M$ testini önermiştir. Pesaran (2004), Breusch ve Pagan (1980)'nın önerdiği $L M$ testini geliştirerek, $C D$ test istatistiğini ortaya koymuştur (Pesaran, 2004: 6). Ayrica Pesaran vd. (2008: 108), $L M$ test istatistiğine varyansı ve ortalamayı da ekleyerek $L M_{a d j}$ test istatistiği önermiştir. Testlerde söz konusu hipotezler şu şekildedir: boş hipoteze göre yatay kesit bağımlılığı söz konusu değilken; alternatif hipoteze göre yatay kesit bağımlılığı bulunmaktadır. Çalışmada ayrıca katsayıların homojen olup olmadığı Swamy (1970) tarafından ortaya atılan ve Pesaran ve Yamagata (2008) tarafından geliştirilen katsayıların homojenliği test edilmiştir. Katsayıların homojenliği $\Delta$ ve $\tilde{\Delta}$ adj test sonuçlarında gösterilmektedir. Burada $\Delta$ test istatistiği büyük örneklem, $\tilde{\Delta}_{a d j}$ test istatistiği ise küçük örneklem için hesaplanmaktadır (Pesaran ve Yamagata, 2008: 56-57).

Tablo 3'de öncelikle değişkenlerde yatay kesit bağımlılı̆̆ının olup olmadığı incelenmiş̧tir. Elde edilen sonuçlara göre değişkenlerde yatay kesit bağımlılığı yoktur boş hipotezi reddedilerek alternatif hipotez kabul edilmiştir. Dolayısıyla çalışmada ele alınan değişkenlerde yatay kesit bağımlılığının olduğu görülmüștür.

Tablo 3: Değişkenlerde Yatay Kesit Bağımlılığı Test Sonuçları

\begin{tabular}{|c|c|c|c|c|c|c|c|c|c|c|}
\hline \multirow{2}{*}{$\begin{array}{l}\text { Sabitli } \\
\text { Model }\end{array}$} & \multicolumn{2}{|c|}{$\operatorname{co} 2$} & \multicolumn{2}{|c|}{ ter } & \multicolumn{2}{|c|}{ govh } & \multicolumn{2}{|c|}{ gdp } & \multicolumn{2}{|c|}{ ensup } \\
\hline & İstatistik & $\begin{array}{l}\text { Olasılık } \\
\text { Değeri }\end{array}$ & İstatistik & $\begin{array}{l}\text { Olasılık } \\
\text { Değeri }\end{array}$ & İstatistik & $\begin{array}{l}\text { Olasılık } \\
\text { Değeri }\end{array}$ & İstatistik & $\begin{array}{c}\text { Olasılık } \\
\text { Değeri }\end{array}$ & İstatistik & $\begin{array}{c}\text { Olasılık } \\
\text { Değeri }\end{array}$ \\
\hline $\begin{array}{c}C D_{l m} \\
(\mathrm{BP}, 1980)\end{array}$ & $36.776 * *$ & 0.018 & 17.183 & 0.700 & 23.330 & 0.327 & $43.383^{*}$ & 0.003 & 20.929 & 0.463 \\
\hline $\begin{array}{l}C D_{l m} \\
\text { (Pesaran, } \\
2004)\end{array}$ & $2.434 *$ & 0.007 & -0.589 & 0.278 & 0.359 & 0.360 & $3.454 *$ & 0.000 & -0.011 & 0.496 \\
\hline $\begin{array}{l}C D \\
\text { (Pesaran, } \\
2004)\end{array}$ & -1.017 & 0.155 & $-2.103 * *$ & 0.018 & $-1.920 * *$ & 0.027 & $-1.801 * *$ & 0.036 & $-1.970 * *$ & 0.024 \\
\hline $\begin{array}{l}L M_{a d j} \\
\text { (PUY, } \\
2008)\end{array}$ & $26.189 *$ & 0.000 & $9.017 *$ & 0.000 & $24.915^{*}$ & 0.000 & 0.568 & 0.285 & $27.064 *$ & 0.000 \\
\hline
\end{tabular}

Not: * **, *** strasıyla $\% 1, \% 5, \% 10$ seviyesinde anlamlılık düzeyini göstermektedir

Tablo 4 'te modele ait yatay kesit bağımlılığı ve homojenite testi sonuçları sunulmaktadır. 
Özcan, G. \& Karter, Ç. (2020), “Çevresel Bozulmalarda Terörizm ve Kamu Harcamalarının Etkisi”, Politik Ekonomik Kuram, 4 (2), 255-268.

Tablo 4.Modelde Yatay Kesit Bağımlılı̆̆ı ve Homojenite Testleri

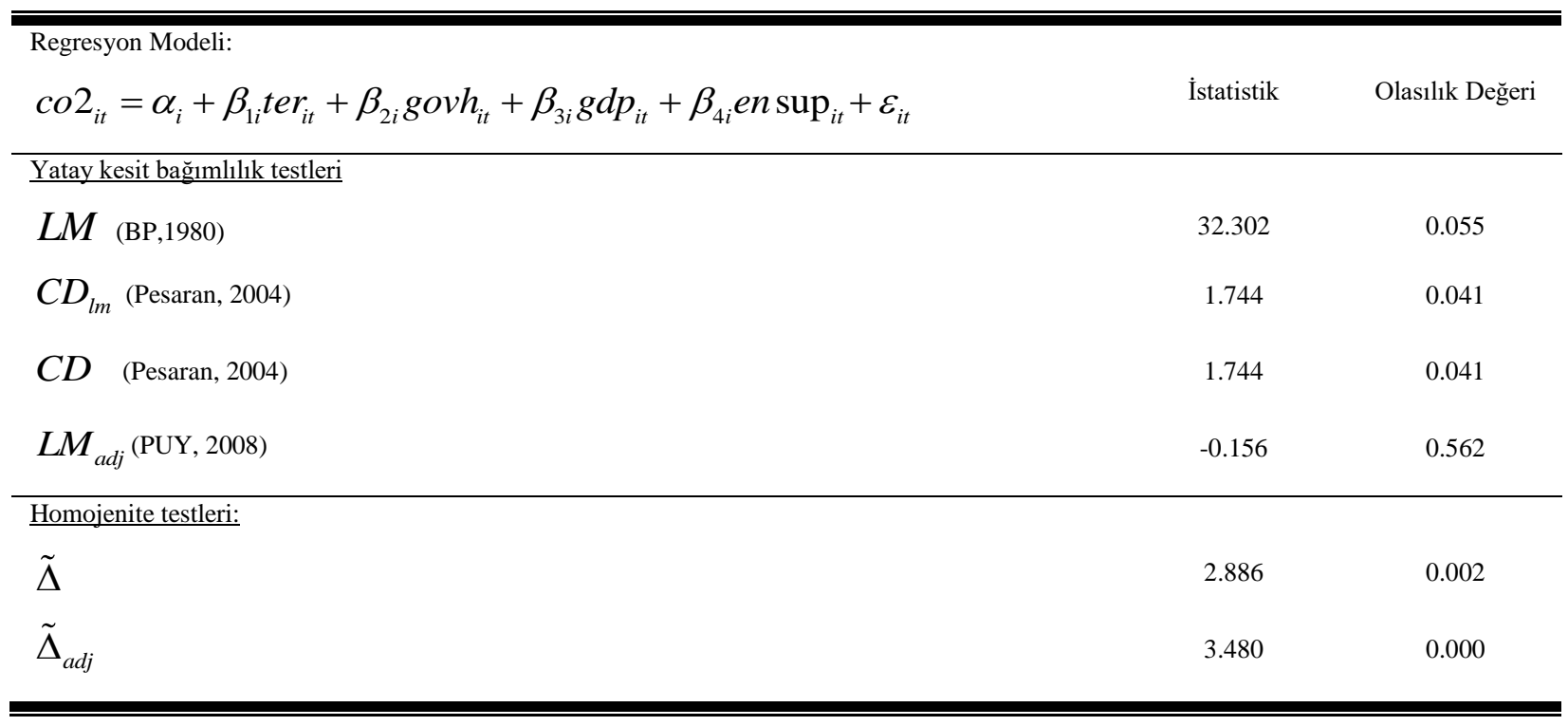

Tablo 4'te modele ait yatay kesit bağımlılığı test sonuçları incelendiğinde yatay kesit bağımlılığının olmadığını belirten boş hipotezin \%5 önem seviyesinde reddedildiği görülmektedir. Dolayısıyla her üç test istatistiği $\left(L M, C D_{L M}, C D\right)$ yatay kesitler birimleri arasında bağımlılık olduğunu diğer bir ifadeyle bir ülkede yaşanan şok karşısında diğer ülkelerin de bu şoktan belli derecelerde etkileneceğini belirtmektedir. Aynı zamanda $\Delta$ ve $\tilde{\Delta}_{a d j}$ test istatistikleri katsayıların homojen olduğu yönündeki boş hipotezin \%1 önem seviyesinde reddedildiğini bir diğer ifadeyle seçilen ülke grubunun heterojen yapıda olduğunu göstermektedir.

\subsection{Hadri ve Kurozumi Panel-KPSS Birim Kök Testi}

Çalışmada serilerin durağanlığını araştırmak için yatay kesit bağımlılığını dikkate alan ve seriyi oluşturan ortak faktörlerin neden olduğu birim kökü de dikkate alarak ortak faktörlerin varlığına izin veren Hadri ve Kurozumi (2012) testi kullanılmıştır. Hadri-Kurozumi Panel-KPSS Birim Kök Testi'nde (Hadri ve Kurozumi, 2012) yatay kesit bağımlılığı ve heterojen yapı dikkate alınarak birim kökün yokluğu hipotezi test edilmektedir. Testte "ZA_spc" ve "ZA_la" olmak üzere iki test istatistiğinden faydalanılmaktadır. "ZA_spc" test istatistiğinde uzun dönem varyansı Sul, Phillips ve Choi (2005) yöntemiyle hesaplanırken, "ZA_la" test istatistiğinde uzun dönem varyansı Choi (1993) ve Toda ve Yamamoto (1995) panel genişletilmiş KPSS testi yöntemiyle hesaplanmaktadır (Hadri ve Kurozumi, 2012). Testlerde söz konusu hipotezler şu şekildedir: boş hipotez serinin durağan olduğunu, alternatif hipotez ise serinin durağan olmadığını ifade etmektedir.

Tablo 5: Hadri ve Kurozumi Panel-KPSS Birim Kök Testi

\begin{tabular}{|c|c|c|c|c|}
\hline \multirow[b]{2}{*}{ Seviyede } & \multicolumn{2}{|c|}{ Sabitli } & \multicolumn{2}{|c|}{ Sabitli ve Trendli } \\
\hline & İstatistik & $\begin{array}{c}\text { Olasılık } \\
\text { Değeri }\end{array}$ & İstatistik & $\begin{array}{c}\text { Olasilık } \\
\text { Değeri }\end{array}$ \\
\hline co2 & & & & \\
\hline ZA_spc & -1.5748 & 0.9423 & 0.6292 & 0.2646 \\
\hline ZA_la & -1.8090 & 0.9648 & 1.2275 & 0.1098 \\
\hline
\end{tabular}


Özcan, G. \& Karter, Ç. (2020), “Çevresel Bozulmalarda Terörizm ve Kamu Harcamalarının Etkisi”, Politik Ekonomik Kuram, 4 (2), 255-268.

\begin{tabular}{|c|c|c|c|c|}
\hline ZA_spc & -1.7639 & 0.9611 & -0.4493 & 0.6734 \\
\hline ZA_la & -1.9708 & 0.9756 & -1.2949 & 0.9023 \\
\hline \multicolumn{5}{|l|}{ govh } \\
\hline ZA_spc & -0.5537 & 0.7101 & -0.9542 & 0.8300 \\
\hline ZA_la & 2.0983 & 0.0179 & 1.4970 & 0.0672 \\
\hline \multicolumn{5}{|l|}{$g d p$} \\
\hline ZA_spc & 0.0892 & 0.4645 & 0.6389 & 0.2614 \\
\hline ZA_la & 0.3714 & 0.3552 & -0.1227 & 0.5488 \\
\hline \multicolumn{5}{|l|}{ ensup } \\
\hline ZA_spc & -1.9901 & 0.9767 & 0.9306 & 0.1760 \\
\hline ZA_la & 0.2988 & 0.3825 & 7.2878 & 0.0000 \\
\hline \multicolumn{5}{|l|}{ Birinci Farkında } \\
\hline \multicolumn{5}{|l|}{ co2 } \\
\hline ZA_spc & -1.7434 & 0.9594 & 0.8622 & 0.1943 \\
\hline ZA_la & -1.8880 & 0.9705 & 1.0795 & 0.1402 \\
\hline \multicolumn{5}{|l|}{ ter } \\
\hline ZA_spc & 0.0430 & 0.4829 & 1.6424 & 0.0503 \\
\hline ZA_la & 0.6153 & 0.2692 & 3.0392 & 0.0012 \\
\hline \multicolumn{5}{|l|}{ govh } \\
\hline ZA_spc & -0.2850 & 0.6122 & 1.9945 & 0.0230 \\
\hline ZA_la & 0.6446 & 0.2596 & 3.6764 & 0.0001 \\
\hline \multicolumn{5}{|l|}{$g d p$} \\
\hline ZA_spc & -0.7003 & 0.7581 & 0.6962 & 0.2432 \\
\hline ZA_la & -0.5061 & 0.6936 & 0.8558 & 0.1961 \\
\hline \multicolumn{5}{|l|}{ ensup } \\
\hline ZA_spc & -0.1449 & 0.5576 & 0.4276 & 0.3345 \\
\hline ZA_la & 1.1313 & 0.1290 & 0.5064 & 0.3063 \\
\hline
\end{tabular}

Not: Maksimum gecikme uzunluğu 4 olarak alınmış ve her bir yatay kesit için optimal gecikme uzunlukları, Schwarz bilgi kriterine göre belirlenmiştir.

ZA_spc: Uzun dönem varyansın Sul et.al(2005) yöntemiyle hesaplandığı panel genişletilmiş KPSS testi

ZA_la: Uzun dönem varyansın Choi(1993) ve Toda\&Yamamoto (1995) yöntemiyle hesaplandığı panel genişletilmiş KPSS testi

ZA_spac ve ZA_la test istatistiklerine göre, tüm seriler için birim kök içermemektedir şeklinde test edilen boş hipotez reddedilmemekte olup serilerin birim kök içermediği yani durağan oldukları tespit edilmiştir. 
Özcan, G. \& Karter, Ç. (2020), “Çevresel Bozulmalarda Terörizm ve Kamu Harcamalarının Etkisi”, Politik Ekonomik Kuram, 4 (2), 255-268.

\subsection{Emirmahmutoğlu-Köse (2011) Nedensellik Testi}

Çalışmada değiş̧kenler arasındaki nedensellik ilişkisini incelemek için Emirmahmutoğlu ve Köse (2011) panel nedensellik testinden yararlanılmıştır. Bu test, zaman serilerindeki Toda- Yamamoto (1995) nedensellik testi mantığına dayanmaktadır. Toda ve Yamamoto (1995) VAR modelinin katsayı sınırlamasını test eden alternatif bir yaklaşım geliştirmiştir. Analiz VAR modelinin en uygun gecikme uzunluğunun (p) saptanması ile başlar. Sonrasında, birim kök testleri ile modeldeki değişkenler için en yüksek bütünleşme derecesi (dmax) saptanır. Daha sonra VAR modeli için belirlenen uygun gecikme uzunluğuna $(p)$ en yüksek bütünleşme derecesi (dmax) ilave edilir. Sonraki aşamada ise VAR modeli $\mathrm{p}+$ dmax gecikme düzeyinde serilerin düzey değerleriyle Panel VAR modeli tahmin edilmektedir.

Emirmahmutoğlu ve Köse (2011) Panel Nedensellik testinden elde edilen panel geneline ve bireysel ülke sonuçlarına Tablo 6'de yer verilmiştir. Panelin geneli için terörizm endeksinden ve kamu harcamalarından $\mathrm{CO}_{2}$ emisyonuna doğru \%1 anlamlılık düzeyinde, tek yönlü bir nedensellik ilişkisi tespit edilmiştir.

Tablo 6: Emirmahmutoğlu ve Köse Panel Nedensellik Analizi

\begin{tabular}{|c|c|c|c|c|c|c|c|c|}
\hline Ülkeler & \begin{tabular}{c}
\multicolumn{1}{c}{ ter } \\
nedeni \\
değildir \\
$\qquad \operatorname{co} 2$
\end{tabular} & $\begin{array}{c}\text { co2 } \\
\text { nedeni } \\
\text { değildir } \\
\text { ter }\end{array}$ & $\begin{array}{c}\text { govh } \\
\text { nedeni } \\
\text { değildir } \\
\text { co2 }\end{array}$ & $\begin{array}{c}\text { co2 } \\
\text { nedeni } \\
\text { değildir } \\
\text { govh }\end{array}$ & $\begin{array}{l}\text { gdp } \\
\text { nedeni } \\
\text { değildir } \\
\text { co2 }\end{array}$ & $\begin{array}{c}\text { co2 } \\
\text { nedeni } \\
\text { değildir } \\
\text { gdp }\end{array}$ & $\begin{array}{c}\text { ensup } \\
\text { nedeni } \\
\text { değildir } \\
\text { co2 }\end{array}$ & $\begin{array}{c}\text { co2 } \\
\text { nedeni } \\
\text { değildir } \\
\text { ensup }\end{array}$ \\
\hline \multirow{2}{*}{ Filipinler } & $4.050 * *$ & 0.369 & $14.996^{*}$ & 0.207 & 0.209 & 0.305 & 1.572 & 0.021 \\
\hline & (0.044) & $(0.543)$ & $(0.000)$ & $(0.649)$ & $(0.648)$ & $(0.580)$ & $(0.210)$ & $(0.885)$ \\
\hline \multirow{2}{*}{ Hindistan } & $4.516^{* *}$ & 0.359 & 0.418 & 0.166 & $5.524 * *$ & 1.078 & 0.217 & 0.203 \\
\hline & $(0.034)$ & $(0.549)$ & $(0.518)$ & $(0.683)$ & (0.019) & (0.299) & $(0.642)$ & $(0.652)$ \\
\hline \multirow{2}{*}{ Irak } & 1.863 & 0.047 & 0.624 & 0.134 & 1.031 & 1.053 & 0.006 & 0.804 \\
\hline & $(0.172)$ & $(0.829)$ & $(0.430)$ & $(0.714)$ & $(0.310)$ & $(0.305)$ & $(0.936)$ & $(0.370)$ \\
\hline \multirow{2}{*}{ Kongo } & 0.879 & 0.250 & 0.646 & $6.079 * *$ & 0.020 & $4.815^{* *}$ & $6.139 * *$ & 0.247 \\
\hline & $(0.348)$ & $(0.617)$ & $(0.422)$ & (0.014) & $(0.887)$ & $(0.028)$ & (0.013) & (0.619) \\
\hline \multirow{2}{*}{ Nijerya } & 0.526 & $5.066 * *$ & 0.051 & 2.393 & 0.016 & 0.444 & 0.659 & 2.315 \\
\hline & $0.468)$ & $(0.024)$ & $(0.821)$ & $(0.122)$ & (0.899) & $(0.505)$ & $(0.417)$ & $(0.128)$ \\
\hline \multirow{2}{*}{ Pakistan } & $20.394 *$ & 0.976 & 1.149 & 0.078 & 0.258 & 1.487 & 0.001 & 0.250 \\
\hline & $(0.000)$ & $(0.323)$ & $(0.284)$ & $(0.780)$ & $(0.611)$ & $(0.223)$ & $(0.982)$ & $(0.617)$ \\
\hline \multirow{2}{*}{ Yemen } & 0.002 & $3.614 * * *$ & $14.912 *$ & 0.535 & 0.526 & 1.314 & 0.851 & 0.212 \\
\hline & $(0.968)$ & $(0.057)$ & $(0.000)$ & $(0.465)$ & $(0.468)$ & $(0.252)$ & $(0.356)$ & $(0.645)$ \\
\hline \multirow{2}{*}{ Panel } & $44.186^{*}$ & 19.163 & $44.099 *$ & 17.123 & 14.118 & 20.142 & 16.643 & 10.000 \\
\hline & $(0.000)$ & $(0.159)$ & $(0.000)$ & $(0.250)$ & $(0.441)$ & $(0.126)$ & $(0.276)$ & $(0.762)$ \\
\hline
\end{tabular}

Not: ${ }^{*}, * * * * *$ sirasıyla $\% 1, \% 5, \% 10$ seviyesinde anlamlılık düzeyini göstermektedir.

Maksimum gecikme sayısı 1 olarak alınmıştır ve her ülke için optimum gecikme Akaike bilgi kriteri aracılığıyla belirlenmiştir."( )" içindeki değerler olasılık değerlerini göstermektedir.

Bireysel ülke sonuçları değerlendirildiğinde, terörizm endeksinin $\mathrm{CO}_{2}$ emisyonunun nedeni olmadığını ifade eden boş hipotez \%1 anlamlılık düzeyinde Pakistan; \%5 anlamlılık düzeyine göre 
Özcan, G. \& Karter, Ç. (2020), “Çevresel Bozulmalarda Terörizm ve Kamu Harcamalarının Etkisi”, Politik Ekonomik Kuram, 4 (2), 255-268.

Filipinler ve Hindistan için reddedilmiştir. Başka bir ifadeyle; Filipinler, Hindistan ve Pakistan'da terörizmden $\mathrm{CO}_{2}$ emisyonuna doğru tek yönlü nedensellik ilişkisi bulunmaktadır. $\mathrm{CO}_{2}$ emisyonundan terörizm endeksine doğru nedenselliğin Nijerya için var olduğu görülmektedir. Kamu harcamalarından $\mathrm{CO}_{2}$ emisyonuna doğru nedenselliğin Filipinler ve Yemen için var olduğu ve boş hipotezin \%1 anlamlılık düzeyinde reddedildiği, $\mathrm{CO}_{2}$ emisyonundan kamu harcamalarına doğru nedenselliğin ise Kongo için var olduğu ve boş hipotezin \%5 anlamlılık düzeyinde reddedildiği görülmektedir. $\mathrm{GSYH}$ 'dan $\mathrm{CO}_{2}$ emisyonuna doğru nedenselliğin Hindistan için geçerli olduğu ve boş hipotezin $\% 5$ anlamlılık düzeyinde reddedildiği, $\mathrm{CO}_{2}$ emisyonundan GSYH'a doğru ise nedenselliğin Kongo için var olduğu ve boş hipotezin $\% 5$ anlamlılık düzeyinde reddedildiği görülmektedir. Enerji arzı endeksinden $\mathrm{CO}_{2}$ emisyonuna doğru nedenselliğin Kongo için var olduğu ve boş hipotezin $\% 5$ anlamlılık düzeyinde reddedildiği, $\mathrm{CO}_{2}$ emisyonundan enerji endeksine doğru ise nedensellik ilişkisinin bulunamadığı görülmektedir.

\section{Sonuç}

Çevrenin kamusal mal niteliğinde olması; çevresel bozulmayı önlemek için kamusal önlemler alınmasını gerektirmektedir. Bu nedenle birçok ülke çevre kirliliğini azaltmak için ciddi çaba sarf etmektedir. Fakat son dönemlerde $\mathrm{CO}_{2}$ emisyonlarının geri döndürülemez seviyelere yükselmiş olması araştırmacıları karbon emisyonuna neden olan etkenleri incelemeye yöneltmiştir.

Çevresel bozulma üzerinde terörizm faaliyetleri en büyük etkenlerden biridir. Çünkü terörizm sadece ekonomik ve sosyal yaşama değil, aynı zamanda çevreye de zarar verici bir etkisi vardır. Terörizm faaliyetleri sırasında çok fazla fosil yakıt kullanılmakta ve ülkeler terörizme karşı askeri silah ve teçhizat kullanımı ile büyük miktarda enerji tüketmektedir.

Bu çalışmada, 2002-2017 dönemleri arasında ele alınan 7 ülkede (Filipinler, Hindistan, Irak, Kongo, Nijerya, Pakistan ve Yemen) çevresel bozulmalar üzerinde kamu harcamaları ve terörizmin etkileri analiz edilmiştir. $\mathrm{CO}_{2}$ emisyonu bağımlı değişken olarak, terörizm, kamu harcamaları, enerji arzı ve GSYH değişkenleri bağımsız değişken olarak kullanılmıştır. Panel veri analizinin uygulandığı çalışmada, ilk olarak değişkenlerde ve modelde yatay kesit bağımlılığının olup olmadığ1 kontrol edilmiş ve ele alınan değişkenlerde ve modelde yatay kesit bağımlılığ1 görülmüştür. Değişkenlerin birinci farklarında birim kök içermediği yani durağan oldukları tespit edilmiştir. Değişkenler arasındaki nedensellik ilişkisini incelemek için Emirmahmutoğlu ve Köse (2011) panel nedensellik testinden yararlanılmıştır. Nedensellik testine göre; Filipinler, Hindistan ve Pakistan'da terörizm endeksinden $\mathrm{CO}_{2}$ emisyonuna doğru, Filipin ve Yemen'de kamu harcamalarından $\mathrm{CO}_{2}$ emisyonuna doğru, Hindistan'da GSYH'dan $\mathrm{CO}_{2}$ emisyonuna doğru, Kongo'da enerji arzından $\mathrm{CO}_{2}$ emisyonuna doğru tek yönlü nedensellik ilişkisi bulunmuştur. Analiz sonucunda elde edilen bulgular terör ve kamu harcamalarının karbon emisyonlarının nedensellik ilişkisini göstererek terör ve kamu harcamalarının çevresel bozulmalarda etkili olduğunu kanıtlar niteliktedir. Terörün çevreye verdiği zararlar sadece karbon emisyonu üzerinde etkili olmasıyla sınırlı olmayıp aynı zamanda diğer boyutlarıyla da kendini göstermektedir. Bu sebeple terörün insan sağlığına etkisi sosyolojik ve psikolojik olmasının yanında çevreyle de görülmekte olup ülkelerin terörle mücadelesinde sadece ekonomik ve iç güvenlik sebepleriyle değil aynı zamanda küresel bir problem olan çevre kirliliği konusu da dikkate alınarak mücadelenin şiddeti arttırılmalıdır. Bununla birlikte kamu harcamalarının çevre kirliliğine etkisi uygulanan politikalarla olumlu ve olumsuz olarak değişebilmektedir. Çevresel bozulmalardaki artış tek bir nedene bağlı olmamakla birlikte sadece ülke içi bir problem de değildir. Küresel boyuttaki bu sorunun çözümü uluslararası işbirliğini gerekli kılmaktadır. 


\section{Kaynakça}

Adewuyi, A.O., 2016. Effects of Public and Private Expenditures on Environmental Pollution: A Dynamic Heterogeneous Panel Data Analysis. Renewable Sustainable Energy Reviews, 65, 489-506.

Bernauer, T. ve Koubi, V., 2006. States as Providers of Public Goods: How Does Government Size Affect Environmental Quality?, Paper presented at the annual meeting of the International Studies Association, Town and Country Resort and Convention Center, San Diego, California, USA Online.

Bildirici, M. ve Gökmenoğlu, S. M., 2020. The impact of Terrorism and FDI on Environmental Pollution: Evidence from Afghanistan, Iraq, Nigeria, Pakistan, Philippines, Syria, Somalia, Thailand and Yemen. Environmental Impact Assessment Review, 81, 1-12.

Biyan, Ö. ve Gök, M., 2014. Çevre Politikaları Kapsamında Avrupa Birliği ve Türkiye'de Çevre Vergilerinin Uygulanışı: Karşılaştırmalı Bir Analiz. Hitit Üniversitesi Sosyal Bilimler Enstitüsü Dergisi, 7, (2), 281-310.

Breusch, T.S. ve Pagan, A.R., 1980. The Lagrange Multiplier Test and Its Applications to Modelspecification Tests in Econometrics. Review of Economic Studies, 47 (1), 239-53.

Carlsson, F. ve Lundström, S., 2001. Political and Economic Freedom and The Environment: The Case of CO2 Emissions. Working Papers in Economics, No 29, (second version), August 2001, Department of Economics, Göteborg University.

Choi, I., 1993. Asymptotic Normality of the Least-Squares Estimates for Higher Order Autoregressive Integrated Process with Some Applications. Econometric Theory, 9(2), 263282.

Cole, A. M., 2004. Us Environmental Load Displacement: Examining Consumption, Regulations and The Role of Nafta. Ecological Economics, 48 (4).

Emirmahmutoğlu, F. ve Köse, N., 2011. Testing for Granger Causality in Heterogeneous Mixed Panels. Economic Modelling, 28, 870-876.

Galinato G.I. ve Galinato S.P., 2016. The Effects of Government Spending on Deforestation Due to Agricultural Land Use Expansion and $\mathrm{CO}_{2}$ Related Emissions. Ecological Economics, $122,43-53$.

Galinato, G.I. ve Islam, A. 2017. The Challenge of Addressing Consumption Pollutants with Fiscal Policy. Environment and Development Economics, 1-24.

Hadri, K. ve Kurozumi, E., 2012. A Simple Panel Stationarity Test in the Presence of Serial Correlation and a Common Factor. Economics Letter, 115, 31-34.

Halkos, G.E., Paizanos, E. A., 2013. The Effect of Government Expenditure on The Environment: An Empirical İnvestigation. Ecological Economics, 91, 48-56.

Halkos, G.E., Paizanos, E. A., 2016. The Effects of Fiscal Policy on $\mathrm{CO}_{2}$ Emissions: Evidence from the USA. Energy Policy, 88, 317-328.

Hrdina, P., Vecerkova, J. and Rehak, D., 2010. Modellıng The Environmental Impacts of Terrorist Attacks. 5th Symposium on Operations Research, Security of Information \& Engineering Cybernetics, 2-6 August, Baden, Germany. 
Ike, G. N., Usman, O. ve Asumadu, S., 2020. Fiscal Policy and $\mathrm{CO}_{2}$ Emissions From Heterogeneous Fuel Sources in Thailand: Evidence From Multiple Structural Breaks Cointegration Test. Science of the Total Environment, 702, 1-11.

Islam, F. ve Lopez, R., 2015. Government Spending and Air Pollution in the U.S. International Review Environmental Resource Economics, 8 (2), 139-189.

Katırcioğlu, S. ve Katırcioğlu, S. 2018. Testing the Role of Fiscal Policy in The Environmental Degradation: The Case of Turkey. Environmental Science and Pollution Research, 25 (6), 5616-5630.

Kaypak, Ş. 2013. Çevre Sorunlarının Çözümünde Küresel Çevre Politikalarının Önemi. Muğla Sitkı Koçman Üniversitesi Sosyal Bilimler Enstitüsü Dergisi, 31, 17-34.

Lopez, R. ve Galinato, G.I. 2007. Should Governments Stop Subsidies to Private Goods? Evidence From Rural Latin America. Journal of Public Economics, 91, 1071-1094.

Lopez, R., Galinato, G. I. ve Islam, A., 2011. Fiscal Spending and The Environment: Theory and Empirics. Journal of Environmental Economics and Management. 62 (2), 180-198.

Lopez, R.E. ve Palacios, A., 2014. Why Has Europe Become Environmentally Cleaner? Decomposing The Roles of Fiscal, Trade and Environmental Policies. Environmental and Resource Economics, 58 (1), 91-108.

Mannion, A. M., 2003. The Environmental Impact of War \& Terrorısm, Geographical Paper, No 169.

Mutlu, A., 2006. Küresel Kamusal Mallar Bağlamında Sağlık Hizmetleri ve Çevre Kirlenmesi: Üretim, Finansman ve Yönetim Sorunları. Maliye Dergisi, 150, 53-78.

Pesaran, M. H., 2004. General Diagnostic Tests for Cross Section Dependence in Panels. Working Paper No:0435, University of Cambridge.

Pesaran, M.H., A. Ullah, ve Yamagata, T., 2008. A Bias-Adjusted LM Test of Error Cross-Section Independence. Econometrics Journal, 11 (1), 105-127.

Peseran, M. H. ve Yamagata, T., 2008. Testing Slope Homogeneity in Large Panels. Journal of Econometrics, 142, 50-93.

Sul, D., Phillips, P.C.B. ve Choi, C., 2005. Prewhitening Bias in HAC Estimation. Oxford Bulletin of Economics and Statistics, 67 (4), 517-546.

Swamy, P.A.V.B., 1970. Efficient Inference in a Random Coefficient Regression Model. Econometrica, 38 (2), 311-323.

Toda, H.Y. ve Yamamoto, T., 1995. Statistical Inference in Vector Autoregressions with Possibly İntegrated Processes. Journal of Econometrics, 66, 225-250.

Yuelan, P., Akbar, M.W., Hafeez, M., Ahmad, M., Zia, Z. ve Ullah, S., 2019. The Nexus of Fiscal Policy Instruments and Environmental Degradation in China. Environmental Science and Pollution Research, 1-14.

Zhang, Q., Zhang, S., Ding, Z. ve Hao, Y., 2017. Does Government Expenditure Affect Environmental Quality? Empirical Evidence Using Chinese city-level data. Journal of Cleaner Production, 161, 143-152. 